\title{
Variables in the acceptability of transitive variants for internally caused verbs of change of state in Romanian $^{\dagger}$
}

\author{
Maria Poponeț* \\ Faculty of Letters, "Babeș-Bolyai” University, Str. Horea 31, 400202 Cluj-Napoca, Romania
}

\author{
Article info \\ History: \\ Received July 4, 2018 \\ Accepted August 11, 2018 \\ Published October 7, 2018 \\ Key words: \\ internally caused verbs of \\ change of state \\ transitive acceptability \\ subject denotation \\ age group \\ valence
}

\begin{abstract}
This paper explores the acceptability of transitive variants for a number of seemingly internally caused verbs of change of state in Romanian, i.e. the verbs express change of state events and lack transitives. To this effect, we designed a linguistic questionnaire which tested the acceptability of transitive counterparts of these verbs, in which we varied the denotation of the subject argument, i.e. natural force vs. agent. The overall results obtained from the 33 participants in the survey revealed the influence of semantic factors on transitive acceptability. The respondents marginally accepted the transitives with natural force subjects, while they rejected the transitives with agent subjects. On the other hand, transitive acceptability varies with the age of the participants, the low scores assigned to the transitives put to the test, irrespective of the denotation of the subject argument, by the youngest group points towards the maintenance of the current valence of these verbs.
\end{abstract}

\section{Introduction}

Within a lexicalist approach to the syntax-semantics interface, Levin \& Rappaport Hovav (1995) suggested the classification of verbs of change of state into externally caused verbs of change of state and internally caused verbs of change of state. Crosslinguistically, the two verb classes are defined by a series of semantic, syntactic and morphological properties.

Thus, externally caused verbs of change of state "imply the existence of an «external cause» with immediate control over bringing about the eventuality denoted by the verb" (Levin \& Rappaport Hovav, 1995 , p. 92), whereas internally caused verbs of change of state denote events where "some property inherent to the argument of the verb is «responsible» for bringing about the eventuality" (Levin \& Rappaport Hovav, 1995, p. 91).

Levin \& Rappaport Hovav (1995, p. 94) put forth the following lexical semantic representation for externally caused verbs of change of state:

\section{(1) $[[\mathrm{x}$ DO-SOMETHING] CAUSE [y BECOME STATE $]]$}

As is apparent from (1), the lexical semantic representation of an externally caused verb of change of state is dyadic, comprising two subevents: a causing subevent [x DO-SOMETHING] and a change of state subevent [y BECOME STATE]. Each subevent contains an argument variable whose semantic role is dictated by the position it occupies in the lexical semantic decomposition: $\mathrm{x}$ is part of the causing subevent and has the semantic role cause, whereas y belongs to the change of state subevent and is a patient.

An externally caused verb of change of state is derived from the dyadic lexical semantic representation in (1) through the lexical binding ${ }^{1}$ of argument $\mathrm{x}$ in the mapping from the lexical semantic representation

\footnotetext{
${ }^{\dagger}$ I would like to thank the anonymous reviewers of this article for their discussions and comments.

*Email address: maria_pop07@yahoo.com.

${ }^{1}$ Lexical binding is synonymous with existential quantification (Levin \& Rappaport Hovav, 1995, p. 108).
} 
to argument structure. The operation of lexical binding captures the idea that there is an external cause in the event expressed by the intransitive. For instance, in the case of an externally caused verb of change of state like English break "our knowledge of the world tells us that the eventuality could not have happened without an external cause" (Levin \& Rappaport Hovav, 1995, p. 93). Importantly, intransitive break has a dyadic lexical semantic representation, while its argument structure is monadic.

Given their derivation from transitive bases ${ }^{2}$, externally caused verbs of change of state show transitive and intransitive variants and take part in the causative alternation [illustrated in (2a,b)], a phenomenon exhibited by pairs of semantically related verbs with transitive and intransitive variants, in which the transitive supplies the cause for the change of state event expressed by the intransitive ${ }^{3}$.

(2) a. John broke the window.

b. The window broke.

In languages with anticausative morphology ${ }^{4}$ (Haspelmath, 1993), externally caused verbs of change of state tend to be morphologically marked.

On the other hand, the lexical semantic representation of internally caused verbs of change of state is monadic, and contains only one event [y BECOME STATE], with the patient argument y, as represented in (3) below:

\section{(3) [y BECOME STATE]}

Internally caused verbs of change of state are basic intransitives which usually lack transitive counterparts, irrespective of the denotation of the subject argument, agent [in (4b) and (5b)] or natural force [in (4c) and $(5 \mathrm{c})]$. Consequently, the verbs do not take part in the causative alternation.

(4) a. The cactus bloomed/blossomed/flowered early.

b. ${ }^{*}$ The gardener bloomed/blossomed/flowered the cactus early.

c. *The warm weather bloomed/blossomed/flowered the cactus early.

(5) a. The logs decayed.

[Levin \& Rappaport Hovav, 1995, p. 97, (33a,b,c)]

b. *The rangers decayed the logs.

c. *The bad weather decayed the logs.

[Levin \& Rappaport Hovav, 1995, p. 97, (34a,b,c)]

In sum, as illustrated by the English data above, externally caused verbs of change of state express externally caused events and show transitive variants, while internally caused verbs of change of state express internally caused events and lack transitive variants. Since only externally caused verbs of change of state have transitive variants, the participation in the causative alternation is restricted to this class.

In the next section, we take a look at a number of Romanian verbs of change of state which lack transitive variants and seem to fall into the class of internally caused verbs of change of state. The investigation of the properties exhibited by these verbs, with special emphasis on the acceptability of transitive variants, might have a bearing not only on the valence of the verbs under study, but also on the relevance of postulating internally caused verbs of change of state.

\footnotetext{
${ }^{2}$ In order to detransitivize, the verbs must leave the nature of the causing event unspecified (Levin \& Rappaport Hovav, 1995, p. 107).

${ }^{3}$ The participation in the causative alternation has been treated as a diagnostic of unaccusativity (Levin \& Rappaport Hovav, 1995), the hypothesis which postulates unaccusative verbs, i.e. intransitive verbs whose surface subjects are underlying objects (Perlmutter, 1978; Burzio, 1986).

${ }^{4}$ Languages with anticausative morphology mark the intransitive members of the alternating pairs.
} 


\section{Internally caused verbs of change of state in Romanian}

Romanian registers intransitive verbs of change of state that lack transitive counterparts (with the relevant meaning) according to Dicționarul explicativ al limbii române (DEX $)^{5}$, out of which we selected the following verbs: a se cloci "go bad", a seprinde (laptele) "(about milk) coagulate", a inflori "blossom", a germina "germinate", a năpîrli "moult", a înmuguri "burgeon", a (se) putrezi "rot", a (se) mucegăi "grow mouldy", a (se) rugini "rust".

For starter, the verbs seem to observe the semantic criterion ascribed to internally caused verbs of change of state as they all depict naturally occurring chemical or biological processes driven by properties of the subject entity.

On the other hand, some verbs, i.e. a se cloci "go bad" and a se prinde (laptele) "(about milk) coagulate", are obligatorily marked with reflexive morphology, which, by common assumptions, signals the derivation from a transitive variant (Haspelmath, 1993; Levin \& Rappaport Hovav, 1995; Chierchia, 2004).

While such morphological arguments challenge the basic intransitivity of a se cloci "go bad" and a se prinde (laptele) "(about milk) coagulate", in what follows, we investigate the tenability of the fixed valence (i.e. the unique intransitivity) of the Romanian verbs above.

\subsection{Semantic variables in the acceptability of transitive variants for internally caused verbs of change of state}

The methodology used involved gathering data on acceptability judgments (traditionally called grammaticality judgments, see Schütze \& Sprouse, 2013) for transitive versions of the verbs listed above, in which we varied the denotation of the entity found in subject position, i.e. natural force vs. agent. Hence, we focused on the grammatical well-formedness of sentences that depends on semantic factors related to the denotation of the entities in subject position.

33 Romanian speakers, aged 20-50, participated in the survey. They agreed to fill in a linguistic questionnaire in which they had to rate 18 sentences on a scale from 1 to 5 (a five-point Likert scale), where 1 stands for "Completely unacceptable", 2 stands for "Almost unusable", 3 means "Debatable", 4 means "Almost perfect", 5 signifies "Perfect" . These gradient acceptability judgments are compatible with a gradient model of grammar (Schütze \& Sprouse, 2013), which advocates several degrees of grammatical acceptability, as opposed to the coarse-grained traditional model which assumed only two options: "ungrammatical' and "grammatical". Thus, the participants were asked to judge sentences according to their own grammar on a scale that ranges from the "Completely unacceptable" endpoint to the "Perfect" endpoint.

We calculated the mean acceptability rating for each sentence, which is the weighted mean, and we also chose to include the minimum and the maximum score received by each sentence. Since the sentences may receive a varied range of scores, we considered that it would be useful to include the mode, i.e. the most frequent value assigned to each sentence.

Table 1 summarizes the results obtained from the 33 speakers consulted.

Despite the fact that these verbs are listed as exclusively intransitives in DEX, some respondents tend to accept transitives with natural force subjects like căldura "the heat", ploaia "the rain" or umezeala "the humidity". Thus, with natural force subjects, the transitives a cloci "cause to go bad" (sentence [1]), a prinde "coagulate" (sentence [3]), a inflori "cause to blossom" (sentence [5]), a germina "germinate" (sentence [7]), a înmuguri "cause to burgeon" (sentence [11]), a putrezi "rot" (sentence [13]), a mucegăi "cause to grow mouldy" (sentence [15]), a rugini "rust" (sentence [17]) were considered to be debatable by rounding the mean rating of each sentence to the nearest whole number ${ }^{7}$, i.e. in these cases, 3 . With a non-agent

\footnotetext{
${ }^{5}$ See also Dragomirescu (2010) for the classification of Romanian unaccusative verbs.

${ }^{6}$ The options in the five-point Likert scale are inspired from Geber (2011), although we reverse her numbering: the "Completely unacceptable" endpoint receives the lowest rating 1, while the "Perfect" endpoint receives the highest rating 5 , and we replace her option "3. Neither good, nor bad" with "3. Debatable".

${ }^{7}$ In what follows, we will employ the mean ratings received by sentences rounded to the nearest whole number.
} 
Sentence

1. Căldura a clocit apa.

"The heat made the water go bad."

2. Ion a clocit apa.

"Ion made the water go bad."

3. Căldura a prins (coagulat) laptele.

"The heat coagulated the milk."

4. Gospodina a prins (coagulat) laptele.

"The housewife coagulated the milk."

5. Căldura a înflorit pomii.

"The heat made the trees blossom."

6. Grădinarul a înflorit pomii.

"The gardener made the trees blossom."

7. Căldura a germinat grîul.

"The heat germinated the wheat."

8. Ion a germinat grîul.

"Ion germinated the wheat."

9. Căldura a năpîrlit păsările.

"The heat made the birds moult."

10. Îngrijitorul a năpîrlit păsările.

"The caretaker made the birds moult."

11. Căldura a înmugurit pomii.

"The heat made the trees burgeon."

12. Grădinarul a înmugurit pomii.

"The gardener made the trees burgeon."

13. Ploaia a putrezit lemnele.

"The rain rotted the logs."

14. Ion a putrezit lemnele.

"Ion rotted the logs."

15. Umezeala a mucegăit pîinea.

"The humidity made the bread grow mouldy."

16. Ion a mucegăit pîinea.

"Ion made the bread grow mouldy."

17. Umezeala a ruginit tabla.

"The humidity rusted the plate."

18. Ion a ruginit tabla.

"Ion rusted the plate."
Mean Min. Max. Mode

2.87

$\begin{array}{llll}1.39 & 1 & 4 & 1\end{array}$

$\begin{array}{llll}3.06 & 1 & 5 & 2 ; 4\end{array}$

$2.21 \quad 1 \quad 4 \quad 1$

$\begin{array}{llll}2.81 & 1 & 5 & 1\end{array}$

$\begin{array}{llll}1.33 & 1 & 3 & 1\end{array}$

$\begin{array}{llll}2.78 & 1 & 5 & 3\end{array}$

$\begin{array}{llll}1.45 & 1 & 3 & 1\end{array}$

$\begin{array}{llll}2.12 & 1 & 5 & 1\end{array}$

$\begin{array}{llll}1.66 & 1 & 5 & 1\end{array}$

$\begin{array}{llll}3.06 & 1 & 5 & 3\end{array}$

$\begin{array}{llll}1.30 & 1 & 3 & 1\end{array}$

$\begin{array}{llll}2.75 & 1 & 5 & 3\end{array}$

$\begin{array}{llll}1.03 & 1 & 2 & 1\end{array}$

$\begin{array}{llll}3.33 & 1 & 5 & 5\end{array}$

$\begin{array}{llll}1.42 & 1 & 5 & 1\end{array}$

$\begin{array}{llll}3.48 & 1 & 5 & 4 ; 5\end{array}$

$\begin{array}{llll}1.54 & 1 & 5 & 1\end{array}$

Table 1: Descriptive statistics of the results of the test for the acceptability of transitive variants for internally caused verbs of change of state

subject, the transitive a năpîrli "cause to moult" (sentence [9]) was judged almost unusable (mean rating 2). A mucegăi "cause to grow mouldy" registers mode 5; a rugini "rust" registers modes 4 and 5; a cloci "cause to go bad", a germina "germinate", a inmuguri "cause to burgeon", a putrezi "rot" have mode 3; a prinde "coagulate" has modes 2 and 4; a inflori "cause to blossom" and a näpîrli "cause to moult" have mode 1 .

With agent subjects, the transitives a cloci "cause to go bad" (sentence [2]), a inflori "cause to blossom" (sentence [6]), a germina "germinate" (sentence [8]), a inmuguri "cause to burgeon" (sentence [12]), a putrezi "rot" (sentence [14]), a mucegăi "cause to grow mouldy" (sentence [16]) were deemed completely 
unacceptable (mean rating 1), whereas a prinde "coagulate" (sentence [4]), a năpîrli "cause to moult" (sentence [10]), a rugini "rust" (sentence [18]) were judged almost unusable (mean rating 2). The mode of these transitive verbs with agent subjects is 1 , which means that most speakers considered the sentences to be completely unacceptable.

The transitives with natural force subjects received the whole range of scores (sentences [1], [3], [5], [7], [9], [11], [13], [15], [17] were assigned scores ranging from the minimum value 1 up to the maximum value 5). Only some of the transitives with agent subjects were assigned the whole range of ratings (sentences [10], [16], [18] received scores from 1 to 5), while the maximum rating of most of the others was lower than 5 (sentences [2] and [4] received maximum 4; sentences [6], [8], [12] received maximum 3 ; sentence [14] received maximum 2).

As these figures show, the transitives with natural force subjects are higher on the acceptability scale than the transitives with agent subjects. Our findings are in line with the assumptions made by Levin (2009), who argued that English internally caused verbs of change of state sometimes show transitives with natural force subjects, but not with agent subjects ${ }^{8}$. Usually, agents cannot manipulate natural forces like heat, rain or humidity, therefore, agents cannot be direct causes of seemingly internally caused events, and cannot show up as subjects of these transitives. On the other hand, heat, rain or humidity can be interpreted as direct causes of such events as evinced by the judgments of the speakers consulted who marginally accepted the transitives with natural force subjects.

Note that Levin's (2009) argumentation accords with the generally accepted view in the literature according to which lexical causatives ${ }^{9}$ express direct causation (although see Neeleman $\&$ van de Koot, 2012, for a distinct opinion $)^{10}$. Thus, the subjects of lexical causatives are considered to be direct causes of the change event named by the verb.

The linguistic questionnaire that we employed gave the respondents the possibility to correct the sentences they found less acceptable and suggest alternatives. The corrections include the use of the intransitive versions of these verbs with causes introduced in adjunct phrases headed by din cauza, din pricina "because of", datorită "due to", de la "from", de "of" or la "at". Some participants avoided using agents even in adjunct phrases headed by din cauza "because of" or datorită "due to", probably because they rule out altogether the status of agents as causes of such events. Other participants resorted to analytical/periphrastic causatives headed by a face "make" as alternatives to the lexical causatives put to the test.

\subsection{Age-related variables in the acceptability of transitive variants for internally caused verbs of change of state}

A variable that one needs to take into account when discussing verb valence is the age of the speakers consulted. Thus, we assume that high scores assigned to transitive variants by younger speakers would point towards a change in the valence of these verbs.

The 33 participants in our survey fall into three groups, according to their age, i.e. the 20-25 age group, the 26-35 age group, and the 36-50 age group. Each age group comprises 11 members.

The participants in the 26-35 and 36-50 age groups have university education, whereas those in the 20-25 age group either have completed their university studies or they are university students. Since from the point of view of education the group is rather homogenous, the level of education was not considered

\footnotetext{
${ }^{8}$ McKoon \& Macfarland (2000, 2002) identified attested examples of transitive variants for internally caused verbs of change of state in English. We also found attested examples in which transitive a putrezi "rot" takes natural force subjects like apa "the water" in (i). An extensive corpus study is left for future research.
}

\begin{tabular}{|c|c|c|c|c|}
\hline Apa & $\begin{array}{l}\text { corodeaz } \breve{a} \\
\text { corrode PRS } 3 \mathrm{SG}\end{array}$ & $\begin{array}{l}\text { oțelul, } \\
\text { steel DET }\end{array}$ & putrezește & lemnul. \\
\hline
\end{tabular}

\footnotetext{
${ }^{9}$ From a syntactic point of view, lexical causatives are transitive verbs.

${ }^{10}$ See also Wolff (2003) on the linguistic coding of directly caused events.
} 
Maria Poponeț

\begin{tabular}{|c|c|c|c|c|}
\hline Sentence & $\begin{array}{l}\text { Mean } \\
\text { (age 20-25) }\end{array}$ & $\begin{array}{l}\text { Mean } \\
\text { (age 26-35) }\end{array}$ & $\begin{array}{l}\text { Mean } \\
\text { (age 36-50) }\end{array}$ & Mean \\
\hline $\begin{array}{l}\text { 1. Căldura a clocit apa. } \\
\text { "The heat made the water go bad." }\end{array}$ & 2.18 & 3.09 & 3.36 & 2.87 \\
\hline $\begin{array}{l}\text { 2. Ion a clocit apa. } \\
\text { "Ion made the water go bad." }\end{array}$ & 1.54 & 1.63 & 1.00 & 1.39 \\
\hline $\begin{array}{l}\text { 3. Căldura a prins (coagulat) laptele. } \\
\text { "The heat coagulated the milk." }\end{array}$ & 2.45 & 3.27 & 3.45 & 3.06 \\
\hline $\begin{array}{l}\text { 4. Gospodina a prins (coagulat) laptele. } \\
\text { "The housewife coagulated the milk." }\end{array}$ & 2.09 & 2.18 & 2.36 & 2.21 \\
\hline $\begin{array}{l}\text { 5. Căldura a înflorit pomii. } \\
\text { "The heat made the trees blossom." }\end{array}$ & 2.27 & 3.09 & 3.09 & 2.81 \\
\hline $\begin{array}{l}\text { 6. Grădinarul a înflorit pomii. } \\
\text { "The gardener made the trees blossom." }\end{array}$ & 1.54 & 1.45 & 1.00 & 1.33 \\
\hline $\begin{array}{l}\text { 7. Căldura a germinat grîul. } \\
\text { "The heat germinated the wheat." }\end{array}$ & 2.27 & 3.27 & 2.81 & 2.78 \\
\hline $\begin{array}{l}\text { 8. Ion a germinat grîul. } \\
\text { "Ion germinated the wheat." }\end{array}$ & 1.72 & 1.54 & 1.09 & 1.45 \\
\hline $\begin{array}{l}\text { 9. Căldura a năpîrlit păsările. } \\
\text { "The heat made the birds moult." }\end{array}$ & 2.27 & 2.45 & 1.63 & 2.12 \\
\hline $\begin{array}{l}\text { 10. Îngrijitorul a năpîrlit păsările. } \\
\text { "The caretaker made the birds moult." }\end{array}$ & 2.45 & 1.63 & 1.00 & 1.66 \\
\hline $\begin{array}{l}\text { 11. Căldura a înmugurit pomii. } \\
\text { "The heat made the trees burgeon." }\end{array}$ & 2.72 & 3.27 & 3.18 & 3.06 \\
\hline $\begin{array}{l}\text { 12. Grădinarul a înmugurit pomii. } \\
\text { "The gardener made the trees burgeon." }\end{array}$ & 1.63 & 1.27 & 1.00 & 1.30 \\
\hline $\begin{array}{l}\text { 13. Ploaia a putrezit lemnele. } \\
\text { "The rain rotted the logs." }\end{array}$ & 2.36 & 3.00 & 2.90 & 2.75 \\
\hline $\begin{array}{l}\text { 14. Ion a putrezit lemnele. } \\
\text { "Ion rotted the logs." }\end{array}$ & 1.09 & 1.00 & 1.00 & 1.03 \\
\hline $\begin{array}{l}\text { 15. Umezeala a mucegăit pîinea. } \\
\text { "The humidity made the bread grow mouldy." }\end{array}$ & 3.18 & 3.63 & 3.18 & 3.33 \\
\hline $\begin{array}{l}\text { 16. Ion a mucegăit pîinea. } \\
\text { "Ion made the bread grow mouldy." }\end{array}$ & 1.63 & 1.54 & 1.09 & 1.42 \\
\hline $\begin{array}{l}\text { 17. Umezeala a ruginit tabla. } \\
\text { "The humidity rusted the plate." }\end{array}$ & 3.18 & 3.54 & 3.72 & 3.48 \\
\hline 18. Ion a ruginit tabla. & 1.81 & 1.72 & 1.09 & 1.54 \\
\hline
\end{tabular}

"Ion rusted the plate."

Table 2: Descriptive statistics of the results of the test for the acceptability of transitive variants for internally caused verbs of change of state distributed on age groups

a variable in the analysis of acceptability judgments. Moreover, the participants lack formal education in linguistics, which means that their judgments were not influenced by theoretical considerations familiar to linguists.

In what follows, we compare the mean ratings assigned to the 18 sentences discussed above by the three age groups, displayed in Table 2.

As the figures show, the difference between the scores assigned to natural force subject transitives and agent subject transitives is greater within the 36-50 age group. This group tends to consider most natural 
force subject transitives debatable: sentences [1], [3], [5], [7], [11], [13], [15] received the mean rating 3; sentence [17] was assigned the mean rating 4 (almost perfect); sentence [9] was assigned the mean rating 2 (almost unusable). Agent subject transitives were rejected more categorically by this group as compared with the other two groups: sentences [2], [6], [8], [10], [12], [14], [16], [18] received the mean rating 1 (completely unacceptable), whereas sentence [4] received the mean rating 2 (almost unusable).

By comparison, the difference between the mean ratings of natural force subject transitives and agent subject transitives is reduced within the 26-35 age group. The natural force subject transitives in sentences [1], [3], [5], [7], [11], [13] received the mean score 3 (debatable), those in sentences [15] and [17] received the mean score 4 (almost perfect), while the transitive in sentence [9] was assigned the mean score 2 (almost unusable). The agent subject transitives in sentences [2], [4], [8], [10], [16], [18] received the mean score 2 (almost unusable), whereas those in [6], [12], [14] were assigned the mean score 1 (completely unacceptable).

The difference between the mean ratings assigned to natural force subject transitives and agent subject transitives is smallest within the 20-25 age group. The natural force subject transitives in sentences [1], [3], [5], [7], [9], [13] received the mean score 2 (almost unusable), while those in [11], [15], [17] received the mean score 3 (debatable). The agent subject transitives in sentences [2], [4], [6], [8], [10], [12], [16], [18] were assigned the mean score 2 (almost unusable), while the transitive in sentence [14] was assigned the mean score 1 (completely unacceptable).

The acceptability of natural force subject transitives is high within the 36-50 age group ( 7 sentences were judged debatable (3), and 1 was deemed almost perfect (4)), reaches a peak within the 26-35 age group ( 6 sentences were considered debatable (3), 2 were judged almost perfect (4)), only to be lowest within the 20-25 age group ( 6 sentences were deemed almost unusable (2), 3 were judged debatable (3)).

On the other hand, agent subject transitives were assigned the lowest scores by the 36-50 age group ( 8 sentences were judged completely unacceptable (1), 1 was deemed almost unusable (2)), followed by the 26-35 age group ( 3 sentences were judged completely unacceptable (1), 6 were considered almost unusable (2)), and the 20-25 age group (1 sentence was deemed completely unacceptable (1), 8 were judged almost unusable (2)).

Although a larger number of speakers need to be questioned before making generalizations, the rejection of the transitive variants of internally caused verbs of change of state, irrespective of the denotation of the subject argument (natural force or agent), by the youngest group may indicate a tendency to maintain the valence of the verbs put to the test.

\section{Conclusions}

Our survey has revealed that the acceptability of the transitive variants of internally caused verbs of change of state in Romanian depends on the denotation of the subject argument. Thus, the transitives with natural force subjects are placed in the middle on the acceptability scale (a five-point Likert scale), whereas the transitives with agent subjects are near the unacceptability end on the scale.

Nonetheless, the more categorical rejection of the transitive variants of these verbs by the youngest group of participants seems to point to the maintenance of the current valence of the verbs.

While there might be a semantic motivation for the basic intransitivity of the verbs that are not marked with reflexive morphology as the verbs express internally caused events in the world, the morphological marking on a se cloci "go bad" and a se prinde (laptele) "(about milk) coagulate" remains unexplained in the context in which these verbs do not show fully acceptable transitives. However, the verbs present transitive variants with different meanings (see DEX), from which such specialized meanings probably developed. Although the intransitives obligatorily marked with reflexive morphology a se cloci "go bad" and a seprinde (laptele) "(about milk) coagulate" may be derived from the transitives a cloci "hatch" and a prinde"catch", the former developed specialized meanings for which the transitive variants are not fully acceptable. The verbs that are obligatorily marked with reflexive morphology and perhaps those with optional morpho- 
logical marking (a (se) putrezi "rot", a (se) mucegăi "grow mouldy", a (se) rugini "rust") show that there is only a partial correlation between internally caused verbs of change of state and morphological marking.

\section{Bibliography}

Burzio, L. (1986). Italian Syntax: A Government and Binding Approach, Reidel, Dordrecht.

Chierchia, G. (2004). A Semantics for Unaccusatives and its Syntactic Consequences, in A. Alexiadou, E. Anagnostopoulou \& M. Everaert (eds), The Unaccusativity Puzzle: Explorations of the Syntax-Lexicon Interface, Oxford University Press, Oxford, p. 22-59, Crossref.

DEX = Dicționarul explicativ al limbii române, [online].

Dragomirescu, A. (2010). Ergativitatea: Tipologie, sintaxă, semantică, Editura Universităţii din Bucureşti, Bucureşti.

Geber, D. (2011). Romanian Dative Clitic Dependencies in Raising Constructions, Teză de doctorat, Universitatea din Ottawa.

Haspelmath, M. (1993). More on the Typology of Inchoative/Causative Verb Alternations, in B. Comrie \& M. Polinsky (eds), Causatives and Transitivity, John Benjamins, Amsterdam, p. 87-120, Crossref.

Levin, B. (2009). Further Explorations of the Landscape of Causation: Comments on the Paper by Alexiadou and Anagnostopoulou, in Proceedings of the Workshop on Greek Syntax and Semantics, MIT Working Papers in Linguistics, Cambridge, p. 239-266, [online].

Levin, B. \& Rappaport Hovav, M. (1995). Unaccusativity: At the Syntax-Lexical Semantics Interface, MIT Press, Cambridge.

McKoon, G. \& Macfarland, T. (2000). Externally and Internally Caused Change of State Verbs, in "Language", vol. 76, iss. 4, p. 833-858, Crossref.

McKoon, G. \& Macfarland, T. (2002). Event Templates in the Lexical Representation of Verbs, in "Cognitive Psychology", vol. 45, p. 1-44, Crossref.

Neeleman, D. \& van de Koot, H. (2012). The Linguistic Expression of Causation, in M. Everaert, M. Marelj \& T. Siloni (eds), The Theta System: Argument Structure at the Interface, Oxford University Press, Oxford, p. 20-51, Crossref.

Perlmutter, D. (1978). Impersonal Passives and the Unaccusative Hypothesis, in J.J. Jaeger et al. (eds), Proceedings of the Fourth Annual Meeting of the Berkeley Linguistics Society, Berkeley Linguistics Society, Berkeley, p. 157-189.

Schütze, C.T. \& Sprouse, J. (2013). Judgment Data, in R.J. Podesva \& D. Sharma (eds), Research Methods in Linguistics, Cambridge University Press, Cambridge, p. 27-50, Crossref.

Wolff, P. (2003). Direct Causation in the Linguistic Coding and Individuation of Causal Events, in "Cognition", vol. 88, p. 1-48, Crossref. 